\title{
Studi Literatur Aktivitas Antibakteri dari Tanaman Famili Malvaceae
}

\author{
Tika Siti Fatimah", Lanny Mulqie \\ Prodi Farmasi, Fakultas Matematika dan Ilmu Pengetahuan Alam, \\ Universitas Islam Bandung, Indonesia. \\ *tikasitifatimah1@gmail.com, lannymulqie.26@gmail.com
}

\begin{abstract}
Infections is one of the problem in the world of health that develops from time to time. Infections caused by bacteria and can be treated with antibiotics. Inappropriate use antibiotics can lead to resistance problem and various unexpected reactions. Therefore, it is necessary to support the treatment of infections, including using natural compounds. One of the plant families that can be used to treat infections is a plant from malvaceae family. This studi aimed to determine the potential antibacterial activity and compounds that contained in plants of malvaceae family. The analysis of this study using literature studies method from various research journals that have been published national and international regarding antibacterial activity and compounds that contained in plants of malvaceae family. Based on literature studies, plants from malvaceae family can inhibit the growth of bacteria such as S. aureus, S. epidermidis, S. mutans, MRSA, E. coli, S. pyogenes, P. aeruginosa, K. pneumonia, S. thypimurium, B. substillis, E. faecali, and P. acnes. Grups of compounds that have the potential as an antibacterial include alkaloids, flavonoids, tannins, saponins, terpenoid, nhexacos-11-enoic acid, stigmasterol, and $\boldsymbol{\beta}$-sitosterol.
\end{abstract}

Keywords: Malvaceae family, antibacterial, bacteria.

\begin{abstract}
Abstrak. Penyakit infeksi adalah salah satu masalah dalam dunia kesehatan yang berkembang dari waktu ke waktu. Infeksi yang disebabkan oleh bakter dapat diobati dengan antibiotika. Penggunaan antibiotika yang tidak tepat dapat menimbulkan masalah resistensi dan berbagai macam reaksi yang tidak diharapkan. Maka dari itu perlu adanya penunjang pengobatan infeksi diantaranya dengan menggunakan bahan alam. Salah satu keluarga tanaman yang dapat digunakan untuk mengobati infeksi adalah tanaman dari famili malvaceae. Tujuan dari penelitian ini adalah untuk mengetahui potensi aktivitas antibakteri dan kandungan senyawa yang terdapat pada tanaman famili malvaceae. Penelitian dilakukan dengan metode penelusuran pustaka melalui jurnal penelitian yang dipublikasikan di jurnal nasional maupun jurnal internasional mengenai aktivitas antibakteri dan kandungan senyawa pada tanaman famili malvaceae. Berdasarkan penelusuran pustaka yang dilakukan, tanaman famili malvaceae dapat menghambat pertumbuhan bakteri. S. aureus, S. epidermidis, S. mutans, MRSA, E. coli, S. pyogenes, P. aeruginosa, K. pneumonia, S. thypimurium, B. substillis, E. faecali, dan P. acnes. Senyawa yang berpotensi sebagai antibakteri diantaranya alkaloid, flavonoid, tanin, saponin, terpenoid, n-hexacos-11-enoic acid, stigmasterol, dan $\boldsymbol{\beta}$-sitosterol.
\end{abstract}

Kata Kunci: Famili malvaceae, antibakteri, bakteri. 


\section{A. Pendahuluan}

Penyakit infeksi adalah salah satu masalah dalam dunia kesehatan yang berkembang dari waktu ke waktu. Infeksi biasanya disebabkan oleh macam-macam mikroorganisme seperti bakteri, virus, fungi, dan protozoa. Terdapat berbagai obat yang digunakan untuk mengobati infeksi yang disebabkan oleh bakteri salah satunya adalah antibiotika. Penggunaan antibiotika yang tidak tepat dapat menimbulkan masalah resistensi dan berbagai macam reaksi seperi hipersesitifitas, keracunan obat, kerusakan sel darah, kerusakan sel saraf, dan gagal ginjal. Dengan adanya efek yang serius maka diperlukan adanya alternatif pengobatan yang lebih aman dan efektif. Salah satu alternatif tersebut adalah dengan memanfaatkan bahan alam (Putri, dkk. 2019). Dengan adanya senyawa di dalam tanaman yang memiliki aktivitas antibakteri memungkinkan dikembangkannya antibiotika yang memiliki efek samping lebih sedikit. Menurut WHO lebih dari 50\% obat klinis berasal dari bahan alam, dan bahan alam berperan penting dalam pengembangan obat di industri farmasi (Ruban, et. al. 2012).

Indonesia merupakan salah satu negara berkembang yang memiliki iklim tropis dan memiliki keanekaragaman yang cukup besar sehingga mempunyai sumber bahan baku obat khususnya obat tradisional yang sudah dimanfaatkan oleh masyarakat secara empiris (Depkes, 2000). Di Amerika Latin, Asia, dan Afrika, sekitar 80\% dari populasi manusia menggunakan obat tradisional sebagai pelengkap pada obat primer (Putri, dkk. 2019). Tanaman yang dapat digunakan untuk mengobati penyakit infeksi diantaranya kembang sepatu (Sarma, dkk. 2016). Tanaman kembang sepatu termasuk ke dalam famili malvaceae (Rendeng, dkk. 2020). Beberapa tanaman yang termasuk ke dalam famili malvaceae ialah kembang sepatu (Hibiscus rosa sinensis L.), rosela (Hibiscus sabdarifa), sidaguri (Sida rhombifolia Linn.), dan kakao (Theobroma cacao L.). Keempat tanaman tersebut memiliki kandungan senyawa seperti flavonoid, alkaloid, tanin, saponin, polifenol, dan triterpenoid.

Rumusan masalah pada studi literatur ini adalah "Bagaimana potensi aktivitas antibakteri dari tanaman famili malvaceae dalam menghambat pertumbuhan bakteri" dan "Apakah senyawa aktif yang mendukung aktivitas antibakteri pada tanaman famili malvaceae". Selanjutnya, tujuan dari studi literatur ini diuraikan dalam pokok-pokok sebagai berikut:

1. Untuk mengetahui bagaimana potensi aktivitas antibakteri dari tanaman famili malvaceae dalam menghambat pertumbuhan bakteri.

2. Untuk mengetahui kandungan yang mendukung aktivitas antibakteri pada tanaman famili malvaceae.

\section{B. Metodologi Penelitian}

Penelitian yang berjudul Studi Literatur Aktivitas Antibakteri Dari Tanaman Famili Malvaceae merupakan penelitian dengan metode penelusuran pustaka melalui jurnal penelitian yang dipublikasikan di jurnal nasional maupun jurnal internasional. Data yang didapatkan berupa data kualitatif dan kuantitatif yang selanjutnya dibahas dan ditarik kesimpulan.

Pada proses pencarian data yang digunakan dalam penelitian dilakukan pencarian jurnal secara langsung melalui situs web pencarian jurnal online. Pencarian jurnal didapatkan melalui situs web resmi seperti Elsevier (Science Direct), Wiley, Springer dan jurnal Scientific Indonesia melalui Google Scholar. Pada penelusuran pustaka jurnal menuliskan kata kunci "aktivitas antibakteri", "antibacterial activity", "tanaman famili malvaceae", "Hibiscus rosasinensis", "Hibiscus sabdariffa", "Sida rhombifolia", dan "Theobroma cacao" dalam bentuk pdf. Sumber data yang diperoleh 17 jurnal yaitu 13 jurnal nasional dan 4 jurnal internasional. Setiap jurnal dilihat pengujian penelitiannya meliputi potensi aktivitas antibakteri dan senyawa yang memiliki aktivitas sebagai antibakteri.

\section{Hasil Penelitian dan Pembahasan}

\section{Potensi Aktivitas Antibakteri}

Penelitian tanaman famili malvaceae terhadap bakteri sudah dilakukan oleh beberapa peneliti. Tanaman yang digunakan pada penelitian ini ialah tanaman kembang sepatu, rosela, sidaguri, dan kakao yang dilakukan terhadap berbagai bakteri uji. 
Tabel 1. Potensi Antibakteri

\begin{tabular}{|c|c|c|c|c|}
\hline Bagian Tanaman & Bakteri uji & $\begin{array}{c}\text { Konsentrasi } \\
(\mathrm{mg} / \mathrm{mL})\end{array}$ & $\begin{array}{c}\text { Zona Hambat } \\
(\mathbf{m m})\end{array}$ & Pustaka \\
\hline $\begin{array}{l}\text { Bunga kembang } \\
\text { sepatu }\end{array}$ & S. aureus & $\begin{array}{l}62,5 \\
125 \\
250 \\
500\end{array}$ & $\begin{array}{l}7,41 \\
8,71 \\
9,65 \\
24,6 \\
\end{array}$ & $\begin{array}{l}\text { Sarma, } \\
(2016)\end{array}$ \\
\hline \multirow{4}{*}{$\begin{array}{l}\text { Daun kembang } \\
\text { sepatu }\end{array}$} & S. epidermidis & 800 & 10,27 & \multirow[b]{2}{*}{$\begin{array}{l}\text { Azzahra, dkk. } \\
\qquad(2018)\end{array}$} \\
\hline & S. mutans & $\begin{array}{l}200 \\
400 \\
800\end{array}$ & $\begin{array}{l}7,27 \\
7,98 \\
8,41\end{array}$ & \\
\hline & MRSA & $\begin{array}{l}200 \\
400 \\
800\end{array}$ & $\begin{array}{l}11,63 \\
13,23 \\
15,90\end{array}$ & $\begin{array}{l}\text { Fathia, dkk. } \\
(2015)\end{array}$ \\
\hline & E. coli & $\begin{array}{c}50 \\
100 \\
200 \\
400 \\
800\end{array}$ & $\begin{array}{l}9,67 \\
11,57 \\
13,58 \\
15,58 \\
17,75\end{array}$ & $\begin{array}{l}\text { Kairupan,dkk. } \\
\text { (2014) }\end{array}$ \\
\hline $\begin{array}{ll}\text { Mahkota } & \text { bunga } \\
\text { rosela } & \\
\end{array}$ & $\begin{array}{l}\text { E. coli } \\
\text { S. aureus }\end{array}$ & $\begin{array}{c}500 \\
750 \\
1000 \\
500 \\
750 \\
1000 \\
\end{array}$ & $\begin{array}{l}8,1 \\
10,5 \\
13,3 \\
8,8 \\
10 \\
13,6 \\
\end{array}$ & $\begin{array}{ll}\text { Purba, } & \text { dkk. } \\
(2020)\end{array}$ \\
\hline Akar rosela & S. aureus & $\begin{array}{l}100 \\
200 \\
300\end{array}$ & $\begin{array}{l}10,48 \\
13,2 \\
12,37 \\
\end{array}$ & $\begin{array}{ll}\text { Putri, } & \text { dkk. } \\
(2019) & \end{array}$ \\
\hline Daun rosela & S. aureus & $\begin{array}{l}100 \\
200 \\
300 \\
\end{array}$ & $\begin{array}{l}12,4 \\
16,73 \\
21,87 \\
\end{array}$ & $\begin{array}{l}\text { Putri, dkk. } \\
\text { (2019) }\end{array}$ \\
\hline Bunga rosela & S. aureus & $\begin{array}{l}100 \\
200 \\
300\end{array}$ & $\begin{array}{l}17,43 \\
21,6 \\
24,23\end{array}$ & $\begin{array}{ll}\begin{array}{l}\text { Putri, } \\
(2019)\end{array} & \text { dkk. }\end{array}$ \\
\hline \multirow{2}{*}{ Kelopak bunga } & S. pyogenes & $\begin{array}{c}50 \\
100 \\
200 \\
400\end{array}$ & $\begin{array}{l}7,1 \\
8,4 \\
10,2 \\
13,3\end{array}$ & Ji, dkk. (2012) \\
\hline & $\begin{array}{l}\text { S. aureus } \\
\text { E. coli } \\
\text { P.aeruginosa } \\
\text { K. pneumoniae }\end{array}$ & $\begin{array}{l}250 \\
250 \\
250 \\
250 \\
\end{array}$ & $\begin{array}{l}22 \\
23 \\
29 \\
33 \\
\end{array}$ & $\begin{array}{l}\text { Sirag, et.al. } \\
\text { (2013) }\end{array}$ \\
\hline \multirow[t]{2}{*}{ Akar sidaguri } & $\begin{array}{l}\text { E. coli } \\
\text { S. thypimurium } \\
\text { S. aureus } \\
\text { P. aeruginosa }\end{array}$ & $\begin{array}{l}50 \\
50 \\
50 \\
50\end{array}$ & $\begin{array}{l}17 \\
18 \\
14,5 \\
13,8 \\
\end{array}$ & $\begin{array}{l}\text { Woldeyes, et. al. } \\
\text { (2012) }\end{array}$ \\
\hline & E. faecalis & $\begin{array}{l}100 \\
150 \\
200 \\
\end{array}$ & $\begin{array}{l}12,67 \\
15,17 \\
17,83 \\
\end{array}$ & $\begin{array}{l}\text { Tanumihardja, } \\
\text { dkk. (2013) }\end{array}$ \\
\hline Kulit buah kakao & $\begin{array}{l}\text { S. aureus } \\
\text { E. coli }\end{array}$ & $\begin{array}{c}80 \\
160 \\
320 \\
640 \\
320 \\
640\end{array}$ & $\begin{array}{l}2,33 \\
4,83 \\
7,33 \\
10 \\
3 \\
8,83\end{array}$ & $\begin{array}{l}\text { Mulyatni,dkk. } \\
\quad(2012)\end{array}$ \\
\hline
\end{tabular}




\begin{tabular}{|l|c|c|l|c|}
\hline & B. substillis & 160 & 2,17 & \\
& & 320 & 6,50 & \\
& P. acnes & 640 & 7,67 & \\
& & 15,81 & 7,50 & \\
& & 31,25 & 9,40 & \\
& 62,50 & 10,70 & Aida, dkk. \\
& & 125 & 13,90 & (2016) \\
& & 500 & 14,70 & \\
& & 1000 & 16,50 & \\
& & 50,80 & \\
\hline
\end{tabular}

Pengujian aktivitas antibakteri dilakukan dengan menggunakan metode difusi agar cara sumuran dan cakram kertas. Tanaman kembang sepatu mampu menghambat bakteri $S$. aureus, S. epidermidis, S. mutans, MRSA, dan E. coli dengan diameter yang bervariasi. Tanaman rosela mampu menghambat bakteri E. coli, S. aureus, S. pyogenes, P. aeruginosa, dan $K$. pneumoniae. Akar sidaguri mampu menghambat bakteri E. coli, S. aureus, $S$. thypimurium, $P$. aeruginosa, dan $E$. faecalis. Sedangkan tanaman kakao dapat menghambat bakteri $S$. aureus, E. coli, B. substillis, dan $P$. acnes.

Fraksi etil asetat bunga kembang sepatu (Hibiscus rosa-sinensis L.) pada konsentrasi 62,$5 ; 125 ; 250$; dan $500 \mathrm{mg} / \mathrm{mL}$ dengan masing-masing diameter zona hambat 7,41; 8,71; 9,65; dan 24,6 mm (Sarma, 2016: 17). Ekstrak etanol daun kembang sepatu (Hibiscus rosa-sinensis L.) dapat menghambat pertumbuhan bakteri S. epidermidis pada konsentrasi $800 \mathrm{mg} / \mathrm{mL}$ dengan diameter zona hambat 10,27 mm. Selain bakteri $S$. epidermidis, ekstrak etanol bunga kembang sepatu dapat menghambat bakteri $S$. mutans pada konsentrasi 200;400; $800 \mathrm{mg} / \mathrm{mL}$ dengan masing-masing diameter zona hambat sebesar 7,27; 7,98; 8,41 mm. Berdasarkan data diatas, maka ekstrak etanol daun kembang sepatu lebih dapat menghambat bakteri S. mutans dibandingkan S. epidermidis karena pada konsentrasi $200 \mathrm{mg} / \mathrm{mL}$ ekstrak etanol bunga kembang sepatu sudah dapat menghambat pertumbuhan bakteri S. mutans (Azzaahra, dkk. 2018). Ekstrak metanol daun kembang sepatu memiliki aktivitas antibakteri terhadap bakteri MRSA pada konsentrasi 200, 300, dan $400 \mathrm{mg} / \mathrm{mL}$ dengan diameter zona hambat berturut-turut yaitu 11,63; 13,23; dan 15,90 mm (Fathia, dkk. 2015). Uji daya hambat ekstrak etanol daun kembang sepatu (Hibiscus rosa-sinensis L.) terhadap bakteri $E$. coli yang dilakukan dengan menggunakan lima konsentrasi berbeda yaitu 50, 100, 200, 400, dan $800 \mathrm{mg} / \mathrm{mL}$. Rata-rata diameter untuk ekstrak etanol daun kembang sepatu berturut-turut adalah 9,67; 11,57; 13,58; 15,58; dan 17,75 mg/mL. Konsentrasi 200 dan $400 \mathrm{mg} / \mathrm{mL}$ merupakan konsentrasi efektif, sedangkan konsentrasi $800 \mathrm{mg} / \mathrm{mL}$ merupakan konsentrasi yang signifikan. Peningkatan konsentrasi ekstrak etanol daun kembang sepatu (Hibiscus rosa-sinensis L.) menunjukkan semakin besar juga daya hambat terhadap bakteri E. coli. Aktivitas antibakteri ekstrak etanol daun kembang sepatu (Hibiscus rosa-sinensis L.) dalam menghambat bakteri $E$. coli lebih peka karena bakteri $E$. coli termasuk ke dalam bakteri gram negatif dimana dinding sel bakterinya terdiri dari satu atau lebih lapisan peptidoglikan yang tipis. Peptidoglikan diperlukan oleh bakteri untuk mempertahankan keutuhan sel (Kairupan, dkk. 2014: 96).

Aktivitas antibakteri infusa mahkota bunga rosela (Hibiscus sabdariffa L.) diujikan terhadap bakteri E. coli dan S. aureus. Berdasarkan diamter zona hambat, maka aktivitas antibakteri infusa mahkota bunga rosela (Hibiscus sabdariffa L.) memiliki potensi aktivitas antibakteri yang tinggi, ditunjukkan dengan rata-rata diameter zona hambat infusa mahkota bunga rosela terhadap bakteri $E$. coli dan $S$. aureus masing-masing 13,3 dan 13,6 mm pada konsentrasi infusa $1000 \mathrm{mg} / \mathrm{mL}$ (Purba, dkk. 2020: 74-75). Pengujian aktivitas antibakteri dari ekstrak etanol akar, daun, dan 
bunga rosela (Hibiscus sabdariffa L.) dilakukan terhadap bakteri S. aureus. Hasil uji aktivitas antibakteri ekstrak akar, daun, dan bunga rosela (Hibiscus sabdariffa L.) dapat dilihat pada Tabel III.1. Ekstrak etanol bunga rosela pada konsentrasi 200 dan $300 \mathrm{mg} / \mathrm{mL}$ adalah konsentrasi yang efektif untuk menghambat pertumbuhan bakteri $S$. aureus sebab pada konsentrasi ekstrak etanol bunga rosela sifat antibakterinya dikategorikan kuat jika dibandingkan dengan akar dan daun (Putri, dkk. 2019). Selain itu, mahkota bunga rosela (Hibiscus sabdariffa L.) dapat menghambat bakteri $S$. pyogenes, $S$. aureus, E. coli, $P$. aeruginosa, dan $K$. pneumoniae dengan diameter zona hambat sangat bervariasi (Ji, dkk. 2012; Sirat, et al. 2013).

Akar sidaguri (Sida rhombifolia Linn.) memiliki aktivitas antibakteri berdasarkan penelitian yang dilakukan oleh Woldeyes, et. al. (2012) dan Tanumihardja, dkk. (2013). Bakteri yang diujikan menggunakan ekstrak akar sidaguri antara lain E. coli, S. aureus, S. thypimurium, $P$. aeruginosa, dan E. faecalis. Pada konsentrasi ekstrak yang sama yaitu $50 \mathrm{mg} / \mathrm{mL}$, dapat menghasilkan diameter yang berbeda pada setiap bakteri. Ekstrak akar sidaguri lebih dapat menghambat bakteri $S$. thypimurium dengan diameter zona hambat sebesar $18 \mathrm{~mm}$ (Woldeyes, et al. 2012). Pengujian aktivitas antibakteri dari ekstrak akar sidaguri (Sida rhombifolia Linn.) terhadap bakteri E. faecalis dilakukan oleh Tanumihardja tahun 2013. Dapat dilihat pada Tabel III.1. bahwa semakin tinggi konsentrasi ekstrak akar sidaguri (Sida rhombifolia Linn.) maka semakin tinggi juga diameter zona hambat yang dihasilkan terhadap bakteri $E$. faecalis. Konsentrasi maksimal yang dapat menghambat pertumbuhan bakteri $E$. faecalis adalah $200 \mathrm{mg} / \mathrm{mL}$ dengan rata-rata diameter zona hambat sebesar $17,83 \mathrm{~mm}$.

Mulyatni, dkk. (2012) dan Aida, dkk. (2016) melakukan penelitian aktivitas antibakteri ekstrak kulit buah dan biji kakao (Theobroma cacao L.) terhadap bakteri $S$. aureus, E. coli, B. substillis, dan P. acnes. Berdasarkan penelitian Mulyatni, dkk. (2012) aktivitas antibakteri ekstrak kulit buah kakao konsentrasi $640 \mathrm{mg} / \mathrm{mL}$ terhadap bakteri $S$. aureus dan E. coli menunjukkan diameter zona hambat yang lebih besar jika dibandingkan dengan diameter zona hambat bakteri $B$. substillis. Perbedaan diameter zona hambat salah satunya disebabkan oleh permeabilitas membran sel bakteri. Membran sel bakteri bersifat selektif permeabel dan setiap sel bakteri mempunyai permeabilitas yang berbeda- beda karena perbedaan struktur membran sel dan enzim yang berfungsi untuk proses penyerapan nutrisi. Hambatan paling besar terjadi pada ekstrak dengan konsentrasi $640 \mathrm{mg} / \mathrm{mL}$ dengan rata-rata diameter hambat $10 \mathrm{~mm}$. Pengujian ekstrak etanol biji kakao (Theobroma cacao L.) pernah dilakukan terhadap bakteri $P$. acnes. Zona hambat hambat mulai terbentuk pada konsentrasi $7,81 \mathrm{mg} / \mathrm{mL}$ hingga konsentrasi $1000 \mathrm{mg} / \mathrm{mL}$. Daya hambat antibakteri ekstrak etanol biji kakao dapat ditentukan dengan nilai breakpoint. Diameter zona hambat terkecil yang terbentuk ialah sebesar 7,50 $\mathrm{mm}$ dan terbesar adalah 16,80 mm (Aida, dkk. 2016).

Parameter adanya aktivitas antibakteri pada pengujian ini adalah terbentuknya zona bening disekitaran sumuran/cakram kertas. Terdapat beberapa kategori daya hambat diantaranya CLSI yang menyatakan apabila daya hambat $<15 \mathrm{~mm}$ tergolong resisten (Azzahra, dkk. 2018). Menurut respon hambatan Morales, suatu antibakteri dikategorikan kuat apabila hambatan yang terbentuk sebesar 11-20 mm (Fathia, dkk. 2015). Sedangkan menurut Greenwood, klasifikasi respon hambatan bakteri jika $<10 \mathrm{~mm}$ dikategorikan tidak terdapat hambatan, 11-15 mm dikategorikan lemah, 16-19 mm dikategorikan sedang, dan $>20 \mathrm{~mm}$ dikategorikan kuat (Putri, dkk. 2019).

Berdasarkan klasifikasi Greenwood rata-rata diameter zona hambat tanaman kembang sepatu masuk ke dalam kategori tidak terdapat hambatan sampai sedang. Tanaman rosela termasuk kategori sedang hingga kuat. Daya hambat dari akar sidaguri dikategorikan lemah, 
dan tanaman kakao dikategorikan tidak terdapat hambatan sampai lemah.

\section{Kandungan Senyawa}

Suatu tanaman dapat berpotensi menghambat pertumbuhan bakteri karena adanya golongan senyawa yang memiliki aktivitas sebagai antibakteri. Golongan senyawa ini dapat menghambat pertumbuhan bakteri dengan satu atau lebih mekanisme senyawa. Berikut adalah senyawa pada tanaman famili malvaceae yang berpotensi sebagai antibakteri:

Tabel 2. Kandungan Senyawa Tanaman Famili Malvaceae

\begin{tabular}{|c|c|c|c|}
\hline Nama Tanaman & Bagian Tanaman & Kandungan Senyawa & Pustaka \\
\hline Kembang sepatu & Bunga & $\begin{array}{l}\text { Flavonoid, alkaloid, tanin, } \\
\text { triterpenoid, fenolik, saponin }\end{array}$ & $\begin{array}{l}\text { Ruban, et. al.(2012) } \\
\text { dan Rendeng, dkk. } \\
(2020) \text {. }\end{array}$ \\
\hline Kembang sepatu & Daun & $\begin{array}{l}\text { Alkaloid, flavonoid, fenol, } \\
\text { saponin, tanin, glikosida }\end{array}$ & Tamboto, dkk. (2017). \\
\hline Rosela & Bunga & $\begin{array}{l}\text { Flavonoid, saponin, tanin, } \\
\text { antosianin }\end{array}$ & Purba, dkk. (2020) \\
\hline Rosela & Akar dan Daun & $\begin{array}{l}\text { Flavonoid, alkaloid, saponin, } \\
\text { steroid, glikosida, tanin }\end{array}$ & Putri, dkk. (2019) \\
\hline Sidaguri & Akar & $\begin{array}{l}\text { Alkaloid, steroid, tanin, } \\
\text { flavonoid, saponin, n- } \\
\text { hexacos-11-enoic acid, } \\
\text { stigmasterol, } \beta \text {-sitosterol }\end{array}$ & $\begin{array}{l}\text { Woldeyes, et. al. } \\
(2012)\end{array}$ \\
\hline Kakao & Kulit biji & $\begin{array}{l}\text { Flavonoid, alkaloid, } \\
\text { polifenol, terpenoid }\end{array}$ & Yumas, (2017) \\
\hline
\end{tabular}

Flavonoid memiliki aktivitas antibakteri karena flavonoid mampu berinteraksi dengan membran sel dan mempengaruhi bioaktivitas membran sel. Selain itu dilaporkan juga bahwa flavonoid mampu mengurangi fluiditas membran sel bakteri yang berhubungan langsung dengan kerusakan membran sitoplasma dan kerusakan tidak langsung melalui autolisis atau pelemahan dinding sel sehingga mengakibatkan lisis osmotik (Purba, dkk. 2020).

Mekanisme kerja saponin sebagai senyawa antibakteri ialah dengan menyebabkan kebocoran enzim dan protein dari sel bakteri. Saponin merupakan senyawa aktif yang dapat meningkatkan permeabilitas membran sel sehinga senyawa antar sel akan berdifusi melalui membran luar dan dinding sel (Purba, dkk. 2020: 76).

Tanin memiliki aktivitas sebagai antibakteri karena tanin dapat menyebabkan sel bakteri menjadi lisis. Hal ini dikarenakan tanin memiliki target kerja pada dinding sel bakteri (dinding polipeptida) sehingga pembentukkan sel tidak sempurna dan sel akan mati. Tanin juga memiliki kemampuan mengganggu jalannya protein di lapisan dalam sel (Purba, dkk. 2020: 76).

Mekanisme terpenoid sebagai agen antibakteri ialah bereaksi dengan porin, dimana porin merupakan protein transmembran pada membran luar dinding sel bakteri sehingga membentuk ikatan polimer kuat yang menyebabkan rusaknya porin. Rusaknya porin akan mengurangi permeabilitas dinding sel bakteri yang mengakibatkan bakteri akan kekurangan nutrisi sehingga pertumbuhan bakteri terhambat atau mati (Wahdaningsih, dkk. 2014: 189).

Secara umum mekanisme alkaloid sebagai antibakteri ialah dengan mengganggu komponen penyusun peptidoglikan pada sel bakteri, jika lapisan dinding sel bakteri tidak terbentuk secara utuh maka akan menyebabkan kematian sel (Wahdaningsih, dkk. 2014: 189).

\section{Kesimpulan}

Berdasarkan pembahasan dalam studi literatur ini, peneliti menyimpulkan beberapa hasil penelitian sebagai berikut:

Tanaman famili malvaceae memiliki aktivitas antibakteri terhadap bakteri Staphylococcus aureus, Staphylococcus epidermidis, Streptococcus mutans, MRSA, 
Escherchia coli, Streptococcus pyogenes, Pseudomonas aeruginosa, Klebsiella pneumoniae, Salmonella thypimurium, Bacillus substillis, Enterococcus faecalis, dan Propionibacterium acnes.

Potensi antibakteri dari tanaman famili malvaceae ditandai dengan terbentuknya zona hambat. Zona hambat yang terbentuk sangat bervariasi tergantung pada konsentrasi ekstrak. Semakin tinggi ekstrak maka semakin besar juga diamater zona hambat yang terbentuk.

Kandungan senyawa bunga kembang sepatu (Hibiscus rosa-sinensis L.) yang berpotensi sebagai antibakteri ialah flavonoid, alkaloid, tanin, fenolik, dan triterpenoid sedangkan pada daun kembang sepatu senyawa yang bersifat sebagai antibakteri adalah alkaloid, flavonoid, fenol, saponin, tanin, dan glikosida. Kandungan senyawa yang bersifat antibakteri pada bunga rosela (Hibiscus sabdariffa L.) adalah flavonoid, saponin, tanin, alkaloid, dan antosianin, pada akar dan daun rosela (Hibiscus sabdariffa L.) mengandung senyawa flavonoid, alkaloid, saponin, steroid, glikosida, dan tanin. Akar sidaguri (Sida rhombifolia Linn.) mengandung senyawa alkaloid, steroid, flavonoid, tanin, dan saponin. Selain itu terdapat pula senyawa isolat yang dapat berpotensi sebagai agen antibakteri pada akar sidaguri ialah n-hexacos-11-enoic acid, stigmasterol, dan $\beta$-sitosterol. Kulit biji kakao (Theobroma cacao L.) mengandung senyawa flavonoid, alkaloid, polifenol, dan terpenoid yang termasuk ke dalam senyawa yang memiliki aktivitas sebagai antibakteri.

\section{Acknowledge}

Terimakasih kepada Ibu Apt. Lanny Mulqie, M.Si. dan Ibu Siti Hazar, M.Si. selaku dosen pembimbing yang telah membimbing dan mengarahkan penulis dalam penulisan ini.

\section{Daftar Pustaka}

[1] Aida, N.A., Suswaty, E., Misnawi. (2016). Uji In Vitro Efek Ekstrak Etanol Biji Kakao (Theobroma cacao L.) sebagai Antibakteri Terhadap Propionibacterium acnes. e-Jurnal Pustaka Kesehatan, Vol.2, No.1 , 127-131.

[2] Azzahra, F., Padmasari, D., Adhiarta, K. (2018). Uji Aktivitas Antibakteri dari Ekstrak Etanol Daun Kembang Sepatu (Hibiscus rosa-sinensis L.) terhadap Bakteri Staphylococcus epidermidis dan Streptococcus mutans. Jurnal Insan Farmasi Indonesia Volume 1, Nomor $2,243-250$.

[3] Depkes, R. (2000). Pedoman Pelaksanaan Uji Klinik Obat Tradisional. Jakarta: Departemen Kesehatan RI.

[4] Fathia, M., Nursanty, R., Saidi, N. (2015). Pengaruh Ekstrak Metanol Daun Kembang Sepatu (Hibiscus rosa-sinensis L.) Terhadap Bakteri Methicillin-resistant Staphylococcus aureus (MRSA). Jurnal Biologi Edukasi Edisi 14, Vol.7, No.1 , 22-28.

[5] Ji, S., Lestari, D.N., Rinanda, D. (2012). Uji Aktivitas Antibakteri Ekstrak Etanol Kelopak Bunga Rosela (Hibiscus sabdariffa L.) Terhadap Streptococcus pyogenes Secara In Vitro. Jurnal Kedokteran Syiah Kuala, Vol.12, No.1 , 31-36.

[6] Kairupan, P.C., Fatimawali., Lolo, A. (2014). Uji Daya Hambat Ekstrak Etanol Daun Kembang Sepatu (Hibiscus rosa-sinensis L.) Terhadap Pertumbuhan Bakteri Escherichia coli. Pharmacon Jurnal Ilmiah Farmasi Vol.3, No.2 , 93-98.

[7] Mulyatni, S., Budiani, A., Taniwiryono, D. (2012). Aktivitas Antibakteri Ekstrak Kulit Buah Kakao (Theobroma cacao L.) Terhadap Escherichia coli, Staphylococcus substillis, dan Staphylococcus aureus. Menara Perkebunan, Vol.80, No.2 , 77-84.

[8] Neu, et. al. (1996). Medical Microbiology 4th Edition. Galveston: University of Texas Medica Branch.

[9] Pelczar, J. M. (2006). Dasar-Dasar Mikrobiologi. Jakarta: Universitas Indonesia.

[10] Pratiwi, H. R. (2017). Mekanisme Pertahanan Bakteri Patogen Terhadap Antibiotika. Jurnal Pro-Life, Volume 4, Nomor 3. 422-423.

[11] Purba, H., Simanjuntak, A., Situmorang, R. (2020). Phytochemical Screening of Bunga Rosela (Hibiscus sabdariffa L.) and Antimicrobacterial Activity Test. Jurnal Pendidikan Kimia, Vol.12, No.2 , 70-78. 
[12] Putri, M., Diana, E., Fitri, K. (2019). Perbandingan Uji Aktivitas Antibakteri Dari Ekstrak Etanol Bunga, Daun, dan Akar Tumbuhan Rosela (Hibiscus sabdariffa L.) Terhadap Bakteri Staphylococcus aureus. Jurnal Dunia Farmasi Vol.3, No.3 , 131-143.

[13] Rendeng, F.E., Kepel, J.B., Manampiring, E. (2020). Uji Anti Mycobacterium Ekstrak Bunga Kembang Sepatu (Hibiscus rosa sinensis L.) sebagai Tumbuhan Obat Anti Tuberkulosis. Jurnal Biomedik Volume 12 Nomor 1 , 48-53.

[14] Ruban, P., Gajalakshmi, K. (2012). In Vitro Antibacterial Activity of Hibiscus rosasinensis Flower Extract Against Human Patogens. Asian Pacific Journal of Tropical Biomedichine , 399-403.

[15] Sarma. (2016). Identifikasi Senyawa Antimikroba Ekstrak Etanol Bunga Kembang Sepatu (Hibiscus rosa-sinensis L.) Terhadap Staphylococcus aureus ATCC25923 Dengan Metode KLT Bioautografi. Jurnal Analisis Labolatorium Medik, Vol.30, No.11 , 12-18.

[16] Sirag, et. al. (2013). Antibacterial Activity of Roselle (Hibiscus sabdariffa L.) Calyx Extract. International Journal of Indigenous Medical Plants, Vol.46, Issues 4, 1487-1491.

[17] Soedarto. (2015). Mikrobiologi Kedokteran. Jakarta: Sagung Seto.

[18] Tamboto, L.J., Homenta, H., Juliantri. (2017). Uji Daya Hambat Ekstrak Daun Kembang Sepatu (Hibiscus rosa-sinensis L.) Terhadap Pertumbuhan Bakteri Porphyromonas gingivalis Secara In Vitro. Pharmacon, Vol.6, No.1 , 31.

[19] Tanumihardja, M., Darmayana., Natsir, N., Mattulada, K.I. (2013). Aktivitas Antibakteri Ekstrak Terstandar Akar Sidaguri (S. rhombifolia) Terhadap E. faecalis dan Actinomyces spp. Dentofasial, Vol.12, No.2 , 90-94.

[20] Tjay, H.T. dan Rahardja, K. (2007). Obat-Obat Penting: Khasiat Penggunaan, dan EfekEfek Sampingnya, Edisi VI Cetakan Pertama. Jakarta: Elex Media Komputindo.

[21] Woldeyes, S., Adane, L., Tariku, Y., Muleta, D., Begashaw, D. (2012). Evaluation of Antibacterial Activities of Compounds Isolated From Sida rhombifolia L. Natural Product Chemistry \& Research, Vol.1, No.1, 1-8.

[22] Wahdaningsih, S., Untara, K.E., Fauziah, Y. (2014). Antibakteri Fraksi n-Heksana Kulit Hylocereus polyrhizus Terhadap Staphylococcus epidermidis dan Propionibacterium acnes. Pharm Sci Res, Vol.1, No.3 , 180-193.

[23] Yumas, M. (2017). Pemanfaatan Limbah Kulit Ari Biji Kakao (Theobroma cacao L.) Sebagai Sumber Antibakteri Streptococcus mutans. Balai Besar Industri Hasil Perkebunan , 7-20. 